\title{
The effect of Propionibacterium acnes on maturation of dendritic cells derived from acne patients' peripherial blood mononuclear cells
}

\author{
Anna Michalak-Stoma ${ }^{1,2}$, Jacek Tabarkiewicz ${ }^{1}$, Alina Olender ${ }^{3}$, \\ Maria Juszkiewicz-Borowiec ${ }^{2}$, Filip Stoma ${ }^{4}$, Aldona Pietrzak ${ }^{2}$, Piotr Pożarowski ${ }^{1}$, \\ Malgorzata Bartkowiak-Emeryk ${ }^{1}$
}

${ }^{1}$ Department of Clinical Immunology, Medical University of Lublin, Poland

${ }^{2}$ Department of Dermatology, Medical University of Lublin, Poland

${ }^{3}$ Department of Clinical Microbiology, Medical University of Lublin, Poland

${ }^{4}$ Department of Neurosurgery, Medical University of Lublin, Poland

\begin{abstract}
Propionibacterium acnes (P. acnes) has been implicated in the pathogenesis of acne vulgaris which is the most common cutaneous disorder. It has a proinflammatory activity and takes part in immune reactions modulating the Th1/Th2 cellular response. The exposure of dendritic cells (DCs) to whole bacteria, their components, cytokines or other inflammatory stimuli and infectious agents induces differentiation from immature DCs into antigen-presenting mature DCs. The aim of the study was to evaluate the capability of $P$. acnes to induce the maturation of DCs. We stimulated monocyte derived dendritic cells (Mo-DCs) from acne patients with various concetrations of heat-killed $P$. acnes $\left(10^{6}-10^{8} \mathrm{bacteria} / \mathrm{ml}\right)$ cultured from acne lesions. The results showed an increase in CD80+/CD86+/DR+ and CD83+/CD1a+/DR+ cells percentage depending on the concetration of $P$. acnes. The expression of CD83 and CD80 (shown as the mean fluorescence intensity - MFI) increased with higher concetrations of $P$. acnes. There were also significant correlations between MFI of CD83, CD80, CD86 and concetration of $P$. acnes. The study showed that $P$. acnes in the concetration of $10^{8}$ bacteria $/ \mathrm{ml}$ is most effective in the induction of Mo-DCs maturation. Futher studies concerning the influence on the function of T cells are needed.
\end{abstract}

Key words: antigen presenting cells (APCs), acne vulgaris, dendritic cells (DCs), Propionibacterium acnes

\section{Introduction}

Acne vulgaris is the most common cutaneous disorder affecting $70-87 \%$ teenagers with a predominance of men [1]. It is manifested by comedones, papules, pustules and cysts. There are many factors in the pathogenesis of acne. The mechanism triggering the development of the comedone and the stimuli causing the non-inflammed lesion to become inflammed are not well known. The microbiology of acne and its immunological implications are the main aim of the present research in the elucidation of the pathogenesis of the inflammatory acne lesions [2,3]. Propionibacterium acnes ( $P$. acnes) has been implicated in the

Correspondence: A. Michalak-Stoma, Dept. of Clinical Immunology, Medical University of Lublin, Al. Racławickie 1, 20-095 Lublin, Poland; tel.: (+4881) 7187416, fax.: (+4881) 7187316, e-mail: annamichalak@wp.pl pathogenesis of acne since its first isolation in 1896. It is now believed that $P$. acnes is a significant contributing factor to the inflammatory stages of the disease [4]. $P$. acnes is an anaerobic Gram-positive bacterium which has a proinflammatory activity and takes part in immune reactions modulating the Th1/Th2 cellular response. The main function of this process depends on dendritic cells (DCs). DCs play an important role in the innate and adaptive immune responses to microbial pathogens [5]. They are the most potent antigen presenting cells (APCs) which function as very efficient activators of naive and resting $T$ cells and restimulators of memory T cells as well as B cells. DCs stimulated with $P$. acnes show increased expression of genes for adhesive molecules and cytokines, which is similar to the response of DCs activated with LPS - a prototype stimulus for DCs maturation [6,7]. Immature DCs are able to capture antigens by phagocytosis, macropinocytosis and endocytosis. Exposure of DCs 
to whole bacteria, their components, cytokines or other inflammatory stimuli and infectious agents induces differentiation of immature DCs into antigen-presenting mature DCs. DCs maturation is a process where major histocompatibility complex (MHC) class I or II and costimulatory molecules (e.g. CD80 and CD86) are upregulated and at the same time specific markers like CD83 and p55 are expressed [5].

The aim of the study was to evaluate the capability of $P$. acnes to induce the maturation of autologous DCs.

\section{Patients and methods}

Patients. Ten men, aged 15-23 years old, suffering from moderate to severe acne vulgaris were included in the study. Skin swab cultures from acne lesions were performed on G.C. Agar Base (Casman) (BIOCORD Poland) in anaerobical conditions over 10 days using GENBags (bioMérieux, France). Next, $P$. acnes were indentified with RAPID ID32A test (bioMérieux, France) and used for preparing bacterial suspensions. Suspensions in $0.9 \% \mathrm{NaCl}$ corresponding to $3.0 \mathrm{McF}$ arland standard $\left(900 \times 10^{6} \mathrm{bacteria} / \mathrm{ml}\right)$ were treated with $0.5 \%$ Phenol analytical grade (SERVA Electrophoresis, Germany) and incubated at $80^{\circ} \mathrm{C}$ over 1.5 hours to kill the bacteria.

Peripheral blood mononuclear cells. Isolation of peripheral blood mononuclear cells (PBMCs) and generation of monocytederived DCs (Mo-DCs) were performed according to previously used protocols [8]. PBMCs from the same individuals were isolated by density gradient centrifugation on Gradisol L (Aqua Medica, Poland). We used EasySep Human CD3 Positive Selection Cocktail and EasySep Magnetic Nanoparticles label CD3+ cells (StemCell Technologies, UK) for magnetic sparation of PBMCs. CD3- cells $(10,000,000$ cells/well) were then cultured in RPMI 1640 (Biomed, Lublin, Poland) supplemented with 10\% human autologous serum and antibiotics (Penicillin-Streptomycin; Sigma, Poland) in 6-well tissue culture plates at $37^{\circ} \mathrm{C}$ in $5 \% \mathrm{CO}_{2}$. After 1.5 hours nonadherent CD3- cells (e.g. CD19+) were removed and the culture plates were washed out by phosphate buffered saline (PBS) without $\mathrm{Ca}^{2+}$ and $\mathrm{Mg}^{2+}$ (Biochrom AG, Germany). CD3- adherent cells were then cultured in the medium described above with mGMP-rhuGM-CSF clinical grade (1000 IU/ml; GENTAUR, Belgium), rhIL-4 (500 $\mathrm{IU} / \mathrm{ml}$; Strathmann, Germany). Cytokines were added on the first, third and fifth day of the culture. On the sixth day of the culture various concentrations of heat-killed P. acnes $\left(10^{6}-10^{8}\right.$ bacteria $\left./ \mathrm{ml}\right)$ were added. After $48 \mathrm{~h}$ adherent cells were detached with $0.02 \%$ tripsin-EDTA solution (Biochrome AG, Germany) and then washed out in PBS without $\mathrm{Ca}^{2+}$ and $\mathrm{Mg}^{2+}$. The cells were counted in the Neubauer chamber for the purpose of estimation of the efficiency of cultures and vitality of cells with tryptan blue.

The control group for the study consisted of PBMC cultures without stimulation with $P$. acnes.

Flow cytometry. The maturation of DCs was determined in a flow cytometer (FACScalibur and CellQuest software). The following combinations of monoclonal antibodies (mAbs) were used: antiCD45/CD14, anti-CD83/CD1a/HLA-DR, and anti-CD80/CD86/ HLA-DR (BectonDickinson Pharmingen, USA). Instrument settings were adjusted with CaliBRITETM3 (BectonDickinson, USA). Samples were evaluated directly after the described protocol, without fixation.

Statistical analysis. The statistical analysis was performed using the Statistica 7.1 PL software and nonparametric Wilcoxon test. $p$ values of 0.05 or less were considered statistically significant. Correlations were calculated using Spearman test.

\section{Results}

After the culture with different concentrations of $P$. acnes $(\mathrm{P} 0$ - culture without $P$. acnes, $\mathrm{P} 6$ - culture with P. acnes $10^{6}$ bacteria/ml, $\mathrm{P} 7$ - culture with $P$. acnes $10^{7}$ bacteria $/ \mathrm{ml}, \mathrm{P} 8$ - culture with $P$. acnes $10^{8}$ bacteria $/ \mathrm{ml}$ ) we evaluated the percentage of cells of the following immunophenotypes:

- $\mathrm{CD} 83+/ \mathrm{CD} 1 \mathrm{a}+/ \mathrm{HLA}-\mathrm{DR}+$

- CD83+/CD1a-/HLA-DR+

- CD83-/CD1a+/HLA-DR+

- $\mathrm{CD} 80+/ \mathrm{CD} 86+/ \mathrm{HLA}-\mathrm{DR}+$

The percentage of cells with CD83+/CD1a+/HLA$\mathrm{DR}+$ increased depending on the $P$. acnes concentration. The significant differences were observed between P0 and P6 $(\mathrm{p}<0.05), \mathrm{P} 0$ and $\mathrm{P} 8(\mathrm{p}=0.005), \mathrm{P} 6$ and $\mathrm{P} 8(\mathrm{p}=0.005)$, and $\mathrm{P} 7$ and $\mathrm{P} 8(\mathrm{p}=0.005)$ (Fig. 1A).

On the contrary, the percentage of CD83+/CD1a/HLA-DR+ cells and CD83-/CD1a+/HLA-DR+ cells decreased with the increase of $P$. acnes concentration. For CD83+/CD1a-/HLA-DR+ cells these differences were statistically significant for P0 and P6 $(\mathrm{p}<0.04)$, P0 and P8 ( $\mathrm{p}=0.005), \mathrm{P} 6$ and P8 $(\mathrm{p}=0.005)$, and P7 and P8 $(p=0.005)$ (Fig. 1B). Significant differences in the population of cells of the immunophenotype CD83/CD1a+/HLA-DR + were noticed between P0 and P7 $(\mathrm{p}<0.03), \mathrm{P} 0$ and P8 $(\mathrm{p}=0.005), \mathrm{P} 6$ and P8 $(\mathrm{p}=0.005)$, and $\mathrm{P} 7$ and $\mathrm{P} 8(\mathrm{p}=0.005)$ (Fig. $1 \mathrm{C})$.

The predominance of cells of $\mathrm{CD} 80+/ \mathrm{CD} 86+/$ HLA-DR+ immunophenotype was observed especially in the cultures with the highest concentration of $P$. acnes. Differences between P0 and P6 $(\mathrm{p}<0.02)$, P0 and P7 $(\mathrm{p}=0.005), \mathrm{P} 0$ and P8 $(\mathrm{p}=0.005), \mathrm{P} 6$ and P8 $(\mathrm{p}=0.005)$, and P7 and P8 $(\mathrm{p}=0.005)$ were statistically significant (Fig. 1D).

We also evaluated the mean fluorescence intensity (MFI) of CD83, CD1a, CD80 and CD86 on DCs, representing the density of the receptors on the cell, derived from PBMCs incubated with different concentration of $P$. acnes. Statistically significant differences were observed for MFI of CD83 in the cultures P0 and P8 $(\mathrm{p}<0.02)$, and P6 and P8 ( $<<0.03)$ (Fig. 2A). A significant difference for MFI of CD1a was seen between P6 and P8 group $(p<0.02)$. Marked statistical differences were noticed for MFI of CD80 between P0 and P8 $(\mathrm{p}=0.005), \mathrm{P} 6$ and P8 $(\mathrm{p}=0.005)$, and P7 and P8 $(p<0.007)$ (Fig. 2B). Differences for MFI of CD86 were not statistically significant.

We observed the correlation between MFI of CD83, CD80, CD86 and concentration of P. acnes (respectively, Spearman's rank correlation coefficient $\mathrm{R}=0.3389,0.5481,0.4563 ; \mathrm{p}<0.05)$.

\section{Discussion}

Propionibacterium acnes causes a range of infections and is associated with many inflammatory conditions. 
A
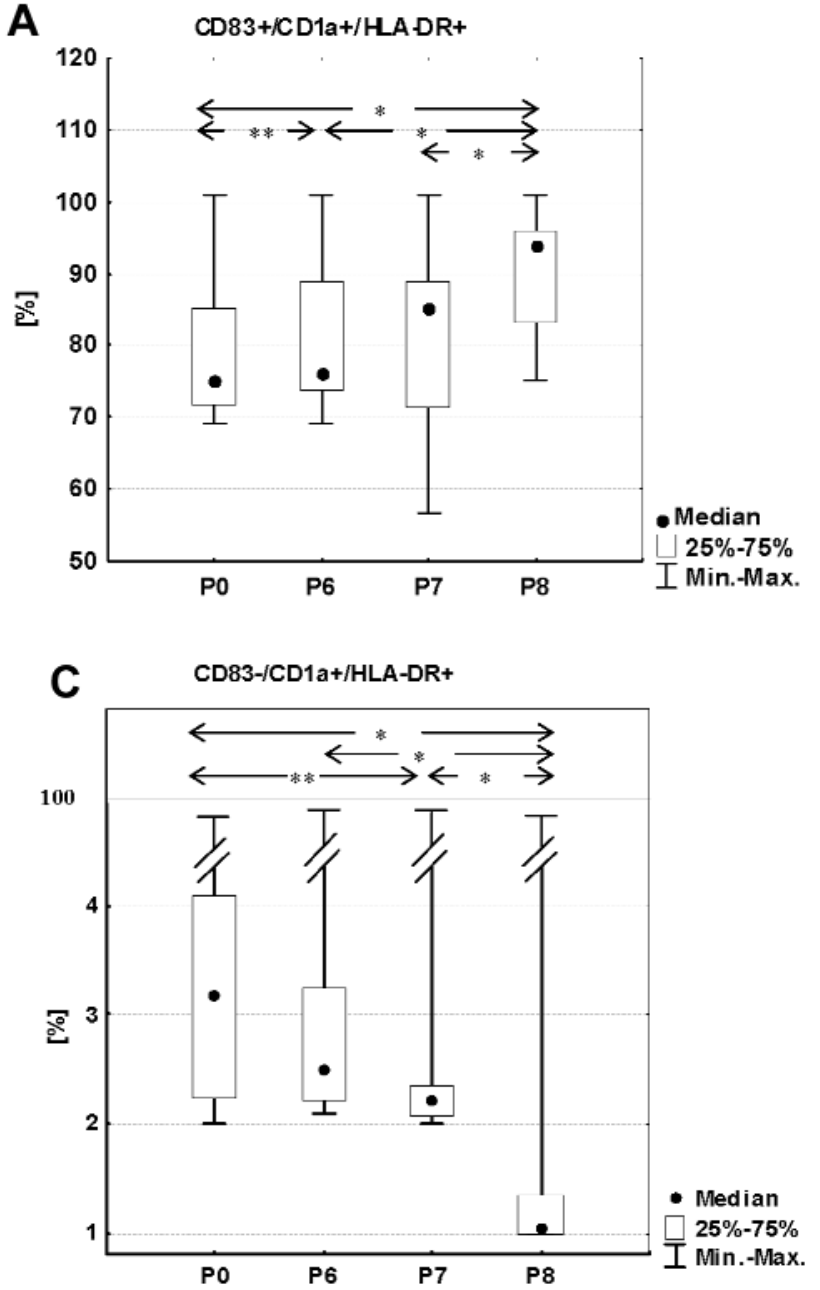

B
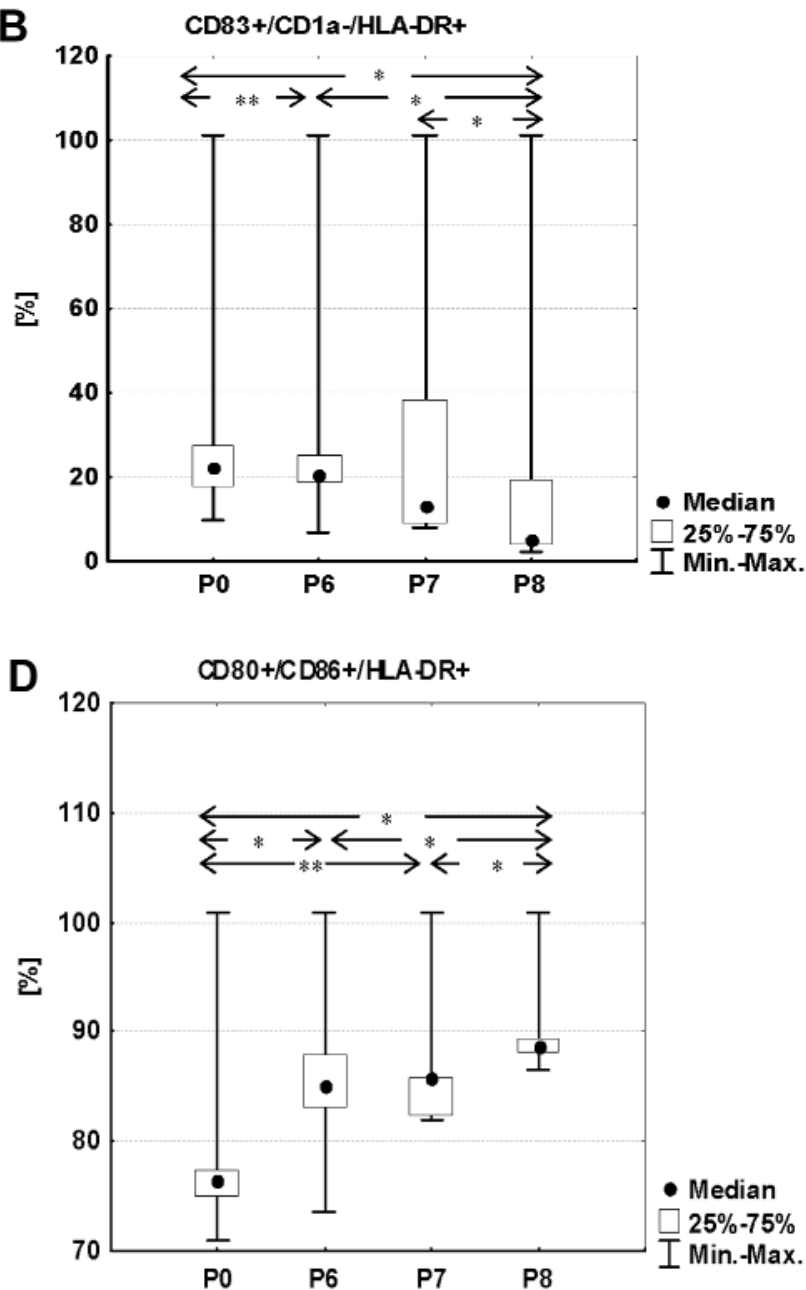

Fig. 1. Evaluation of cells of selected immunophenotypes after the culture with different concentrations of $P$. acnes $(\mathrm{P} 0$ - culture without $P$. acnes, $\mathrm{P} 6$ - culture with $P$. acnes $10^{6}$ bacteria $/ \mathrm{ml}, \mathrm{P} 7$ - culture with $P$. acnes $10^{7}$ bacteria $/ \mathrm{ml}, \mathrm{P} 8$ - culture with $P$. acnes $10^{8}$ bacteria/ml). A. Percentage of cells of CD83+/CD1a+/HLA-DR+ immunophenotype. Significant differences between P0/P6, P0/P8, P6/P8 and P7/P8. $*(\mathrm{p}=0.005), * *(\mathrm{p}<0.05)$. B. Percentage of cells of CD83+/CD1a-/HLA-DR+ immunophenotype. Significant differences between P0/P6, $\mathrm{P} 0 / \mathrm{P} 8, \mathrm{P} 6 / \mathrm{P} 8$ and P7/P8. *(p=0.005), **(p<0.04). C. Percentage of cells of CD83-/CD1a+/HLA-DR+ immunophenotype. Significant differences between P0/P7, P0/P8, P6/P8 and P7/P8. * $(\mathrm{p}=0.005), * *(\mathrm{p}<0.03)$. D. Percentage of cells of CD80+/CD86+/HLA-DR+ immunophenotype. Significant differences between P0/P6, P0/P7, P0/P8, P6/P8 and P7/P8. *(p=0.005), **(p<0.02).

Apart from its involvement in the pathogenesis of acne vulgaris [3] P. acnes is associated with synovitis, acne, pustulosis, hyperostosis and osteitis (SAPHO) [9], and infections of the central nervous system, endocardium, joints, eyes, bone marrow and articular discs after surgical procedures [10]. Roszkowski et al. studied the modulation of the immune system by propionibacteria and showed that $P$. acnes is one of the most potent adjuvants [11]. It was shown that pretreatment with heat-killed cells of $P$. acnes provides protection against infection and anti-tumor activity in animal models [12]. In some Polish research centres autovaccines prepared from the patient cultures of $P$. acnes and/or Staphylococcus (epidermidis, aureus) are used. However, there is not much evidence of the efficacy of this treat- ment in acne vulgaris [13-15]. It should be considered if vaccines with DCs loaded with $P$. acnes antigen were more effective in the acne therapy.

In this study we would like to evaluate the capability of $P$. acnes to induce the maturation of DCs. We would like to choose the concentration of $P$. acnes which induces the strongest modulation of Mo-DCs. The stimulation of Mo-DCs with P. acnes resulted in their maturation to APCs, as evidenced by enhanced expression of cell surface molecules CD83, CD80, CD86 and HLA-DR. The results showed an increase of CD80+/CD86+/DR + cells percentage depending on the concetration of $P$. acnes. Subpopulations of CD83+/CD1a+/DR+, CD83+/CD1a-/DR+ and CD83$/ \mathrm{CD} 1 \mathrm{a}+/ \mathrm{HLA}-\mathrm{DR}+$ cells were observed, however the 

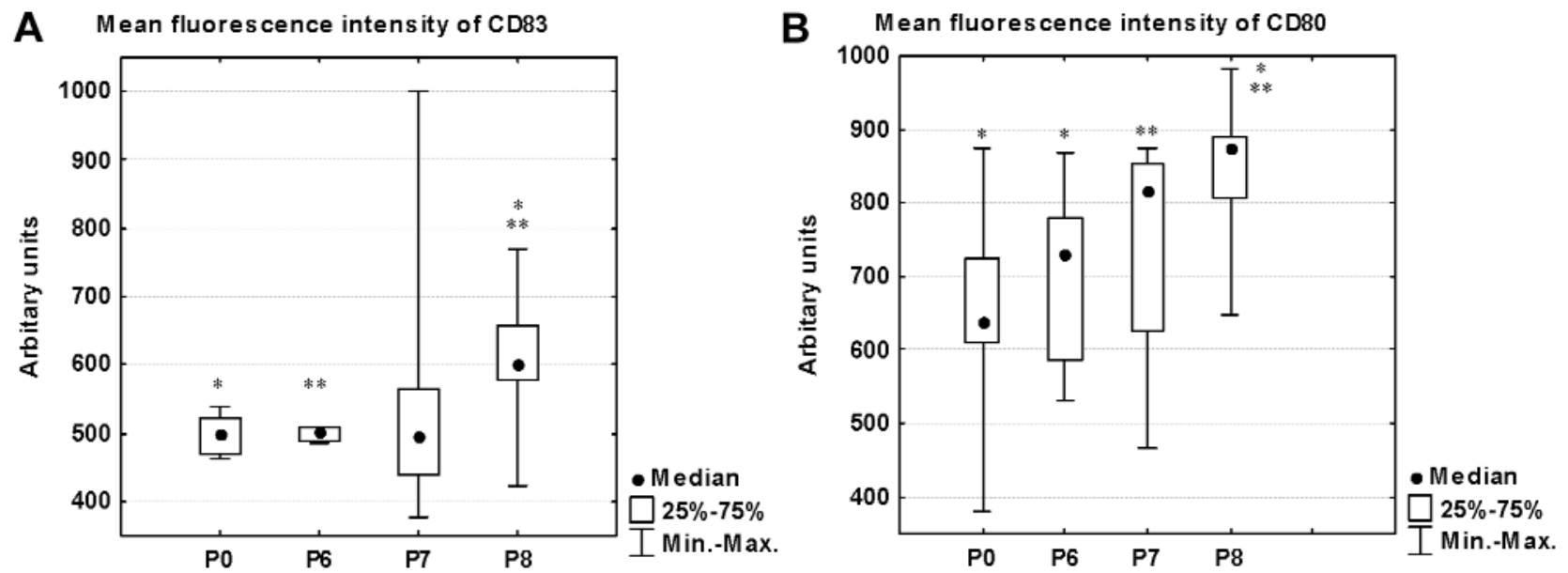

Fig. 2. Mean fluorescence intensity (MFI) of CD83 and CD80 on DCs derived from PBMCs incubated with different concentration of $P$. acnes (P0 - culture without $P$. acnes, $\mathrm{P} 6$ - culture with $P$. acnes $10^{6}$ bacteria $/ \mathrm{ml}, \mathrm{P} 7$ - culture with $P$. acnes $10^{7}$ bacteria/ml, $\mathrm{P} 8$ - culture with $P$. acnes $10^{8}$ bacteria/ml). A. Mean fluorescence intensity of CD83 on DCs. Significant differences between P0/P8 and P6/P8. $*(p<0.02), * *(p<0.03)$. B. Mean fluorescence intensity of CD80 on DCs. Significant differences between P0/P8, P6/P8 and P7/P8. $*(\mathrm{p}=0.005), * *(\mathrm{p}<0.007)$.

population of $\mathrm{CD} 83+/ \mathrm{CD} 1 \mathrm{a}+/ \mathrm{DR}+$ increased, and CD83+/CD1a-/DR+ and CD83-/CD1a+/HLA-DR+ decreased dose-dependently. The expression of CD83 and CD80 (shown as MFI) increased with higher concentrations of $P$. acnes. There were also correlations between MFI of CD83, CD80, CD86 and concentrations of $P$. acnes.

There are no similar studies comparing the influence of different concentrations of $P$. acnes on the DC maturation. Kopitar et al. stimulated Mo-DCs with different oral bacterial antigens (prepared from Streptococcus mitis, Propionibacterium acnes and Bacteroides spp.) and observed an enhanced expression of CD83, CD80 and HLA-DR compared with monocytes at the beginning of the experiment [16]. Cervi et al. showed up-regulation of the surface expression of CD80 and MHC II in mice injected with P. acnes [17]. A similar experiment was conducted by Squaiella et al. They investigated the role of $P$. acnes and its soluble polysaccharide extract on murine bone marrow DCs. The increase of CD80 and CD86 expression was observed [18].

Similarly, enteric pathogens, such as Campylobacter jejuni [5], Salmonella enterica serovar Typhimurium (S. typhimurium) [19], Helicobacter pylori [20] and Escherichia coli [21] have been shown to up-regulate the expression of cell surface costimulatory molecules CD40, CD83, CD80 and CD86, and MHC II in the immature DCs stimulated with the aforementioned bacteria.

Veckman et al. characterized the effect of Lactobacillus rhamnosus (L. rhamnosus) and Streptococcus pyogenes (S. pyogenes) on the expression of CD80, CD83 and CD86 after 24h-culture with different doses of bacteria. They observed that $S$. pyogenes stimulated the expression of CD83 and CD86 better than L. rhamnosus. The best bacteria:DC ratio after the experiments with different bacteria concentrations was estimated for 5:1 [22]. Veckman et al. evaluated also plasmacytoid DCs (PDCs) and myeloid DCs (MDCs) stimulated with Streptococcus pyogenes at 5:1 bacteria: DC ratios for $24 \mathrm{~h}$ or $48 \mathrm{~h}$ and with influenza A virus. The expression of CD86 in PDCs after 24h stimulation was slightly increased, however after $48 \mathrm{~h}$ it was higher in microbe-stimulated PDCs. Stimulation of MDCs with $S$. pyogenes resulted in significantly increased expression of CD40 and CD86 at 24h and 48h [23].

The strong up-regulation of CD83 expression was observed also in DCs infected with Listeria monocytogene, Treponema pallidum and Mycobacterium tuberculosis [24].

Lactobacillus casei simillary to L. rhamnosus induced a moderate maturation of DCs in the presence of epithelium - a low increase in CD86 and CD54 expression [25]. Lactobacillus plantarum induced a lower expression of CD80 and CD83 compared with Gram-negative pathogenic bacteria [26].

On the contrary, Mycobacterium leprae [27], Coxiella burnetti [28] and pneumococcal polysaccharides [29] do not induce DC maturation.

On the basis of the presented experiments we would like to use $P$. acnes in the concentration of $10^{8}$ bacteria/ml for further studies concerning the influence on functions of T cells. Some studies were conducted to evaluate the immune response after the stimulation with DCs copulsed with $P$. acnes in animal models [17,30], however there is still not enough knowledge on the influence of DCs primed with 
$P$. acnes on T cell functions [16,31]. This knowledge is important for better understanding of the immunopathology of acne vulgaris. It also offers new possibilities for modulating the immune response with vaccination of DCs loaded with $P$. acnes antigen in acne vulgaris patients.

Acknowledgments: This work was supported by grant of Ministry of Science and Higher Education in Poland No 2 P05B 07430.

\section{References}

[1] Dreno E, Poli F. Epidemiology of Acne. Dermatology. 2003;206:7-10.

[2] Burkhart CG, Burkhart CN, Lehmann PF. Acne: a review of immunologic and microbiologic factors. Postgrad Med J. 1999; $75: 328-331$

[3] Leyden JJ. The evolving role of Propionibacterium acnes in acne. Semin Cutan Med Surg. 2001;20:139-143.

[4] Farrar MD, Ingham E. Acne: Inflammation. Clin Dermatol. 2004;22:380-384

[5] Hu L, Bray MD, Osorio M, Kopecko DJ. Campylobacter jejuni induces maturation and cytokines production in human dendritic cells. Infect Immun. 2006;74:2697-2705.

[ 6] Verhasselt V, Buelens C, Willems F, De Groote D, HaeffnerCavaillon N, Goldman M. Bacterial lipopolysaccharide stimulates the production of cytokines and the expression of costimulatory molecules by human peripheral blood dendritic cells: evidence for a soluble CD14-dependent pathway. $J$ Immunol. 1997; 158:2919-2925.

[ 7] Winzler C, Rovere P, Rescigno M, et al. Maturation stages of mouse dendritic cells in growth factor-dependent long-term cultures. J Exp Med. 1997;185:317-328.

[ 8] Tkachenko N, Wojas K, Tabarkiewicz J, Rolinski J. Generation of dendritic cells from human peripheral blood monocytes - comparison of different culture media. Folia Histochem Cytobiol. 2005;43:25-30.

[9] Schaeverbeke T, Lequen L, De Barbeyrac B, et al. Propionibacterium acnes isolated from synovial tissue and fluid in a patient with olgoarthritis associated with acne and pustulosis. Arthritis Rheum. 1998;41:1889-1893.

[10] Perry AL, Lambert PA. Propionibacterium acnes. Lett Appl Microbiol. 2006;42:185-188.

[11] Roszkowski W, Roszkowski K, Ko HL, Beuth J, Jeljaszewicz J. Immunomodulation by propionibacteria. Zentralbl Bakteriol. 1990;274:289-298.

[12] Eady EA, Ingham E. Propionibacterium acnes - friend of foe? Rev Med Microbiol. 1994;5:163-173.

[13] Dmochowski M. Rola Propionibacterium spp. w etiopatogenezie trądzika pospolitego w świetle wyników leczenia szczepionką wstrzykiwaną podskórnie sporządzoną $\mathrm{z}$ tych bakterii oraz erytromycyną stosowana zewnętrznie. Postępy Dermatologii. 1991;8:405-464.

[14] Rubisz-Brzezińska J, Wilk-Czyż R, Brzezińska-Wcisło L, Kasprowicz A. Ocena kliniczna ciężkich postaci trądzika leczonych autoszczepionką. Med Dośw Mikrobiol. 1994;46:35-42.

[15] Zaluga E. Odczyny skórne na antygeny Propionibacterium acnes $\mathrm{u}$ pacjentów $\mathrm{z}$ trądzikiem pospolitym leczonych autoszczepionką. Ann Acad Med Stetin. 1998;44:65-85.

[16] Kopitar AN, Ihan Hren N, Ihan A. Commensal oral bacteria antigens prime human dendritic cells to induce Th1, Th2 or Treg differentiation. Oral Microbiol Immunol. 2006;21:1-5.
[17] Cervi L, MacDonald AS, Kane C, Dzierszinski F, Pearce EJ. Cutting edge: dendritic cells copulsed with microbial and helminth antigens undergo modified maturation, segregate the antigens to distinct intracellular compartments, and concurrently induce microbe-specific Th1 and helminth-specific Th2 responses. J Immunol. 2004;172:2016-2020.

[18] Squaiella CC, Ananias RZ, Mussalem JS, et al In vivo and in vitro effect of killed Propionibacterium acnes and its purified soluble polysaccharide on mouse bone marrow stem cells and dendritic cell differentiation. Immunobiology. 2006;211:105116.

[19] Norimatsu M, Chance V, Dougan G, Howard CJ, VillarrealRamos B. Live Salmonella enterica serovar Typhimurium ( $S$. typhimurium) elicit dendritic cell responses that differ from those induced by killed $S$. typhimurium. Vet Immunol Immunopathol. 2004;98:193-201.

[20] Kranzer K, Eckhardt A, Aigner M, et al. Induction of maturation and cytokine release of human dendritic cells by Helicobacter pylori. Infect Immun. 2004;72:4416-4423.

[21] Ferlazzo G, Morandi B, D'Agostino A, et al. The interaction between NK cells and dendritic cells in bacterial infections resulted in rapid induction of NK cell activation and in the lysis of uninfected dendritic cells. Eur J Immunol. 2003;33: 306-313.

[22] Veckman V, Miettinen M, Pirhonen J, Siren J, Matikainen S, Julkunen I. Streptococcus pyogenes and Lactobacillus rhamnosus differentially induce maturation and production of Th1type cytokines and chemokines in human monocyte-derived dendritic cells. J Leukoc Biol. 2004;75:764-771.

[23] Veckman V, Julkunen I. Streptococcus pyogenes activates human plasmacytoid and myeloid dendritic cells. J Leukoc Biol. 2007;83:1-9.

[24] Shin JL, Chung KY, Kang JM, Lee TH, Lee MG. The effect of Treponema pallidum on human dendritic cells. Yonsei Med J. 2004;45:515-522.

[25] Ratajczak C, Duez C, Grangette C, Pochard P, Tonnel AB, Pestel J. Impact of lactic acid bacteria on dendritic cells from allergic patients in an experimental model of intestinal epithelium. J Biomed Biotechnol. 2007;1:1-9.

[26] Rimoldi M, Chieppa M, Larghi P, Vulcano M, Allavena P, Rescigno M. Monocyte-derived dendritic cells activated by bacteria or by bacteria-stimulated epithelial cells are functionally different. Blood. 2005;106:2818-2826.

[27] Murray RA, Siddiqui MR, Mendillo M, et al. Mycobacterium leprae inhibits dendritic cell activation and maturation. J Immunol. 2007;178:338-344.

[28] Shannon JG, Howe D, Heinzen RA. Lack of dendritic cell maturation following infection by Coxiella burnetii synthesizing different lipopolysaccharide chemotypes. Ann $N Y$ Acad Sci. 2005;1063:154-160.

[29] Meltzer U, Goldblatt. Pneumococcal polysaccharides ineracts with human dendritic cells. Infect Immun. 2006;74:18901895.

[30] Matsui K, Yoshimoto T, Tsutsui H, et al. Propionibacterium acnes treatment diminishes $\mathrm{CD} 4{ }^{+} \mathrm{NK} 1.1^{+} \mathrm{T}$ cells but induces type I T cells in the liver by induction of IL-12 and IL-18 production from Kupffer cells. J Immunol. 1997;159:97-106.

[31] Mouser PE, Baker BS, Seaton ED, Chu AC. Propionibacterium acnes-reactive $\mathrm{T}$ helper- 1 cells in the skin of patients with acne vulgaris. J Invest Dermatol. 2003;121:1226-1228.

Submitted: 3 February, 2008 Accepted after reviews: 25 June, 2008 